\title{
Effects of Coal-Mine Drainage on Stream Water Quality in the Allegheny and Monongahela River Basins- Sulfate Transport and Trends
}

by James I. Sams III and Kevin M. Beer

Water-Resources Investigations Report 99-4208

National Water-Quality Assessment Program 


\title{
U.S. DEPARTMENT OF THE INTERIOR
}

\section{BRUCE BABBITT, Secretary}

\author{
U.S. GEOLOGICAL SURVEY
}

Charles G. Groat, Director

For additional information write to:

\section{District Chief}

U.S. Geological Survey

840 Market Street

Lemoyne, Pennsylvania 17043-1586
Copies of this report may be

purchased from:

U.S. Geological Survey

Branch of Information Services

Box 25286

Denver, Colorado 80225-0286 


\section{FORE WORD}

The mission of the U.S. Geological Survey (USGS) is to assess the quantity and quality of the earth resources of the Nation and to provide information that will assist resource managers and policymakers at Federal, State, and local levels in making sound decisions. Assessment of water-quality conditions and trends is an important part of this overall mission.

One of the greatest challenges faced by water-resources scientists is acquiring reliable information that will guide the use and protection of the Nation's water resources. That chal lenge is being addressed by Federal, State, interstate, and local water-resource agencies and by many academic institutions. These organizations are collecting water-qual ity data for a host of purposes that include: compliance with permits and water-supply standards; devel opment of remediation plans for a specific contamination problem; operational decisions on industrial, wastewater, or water-supply facilities; and research on factors that affect water quality. An additional need for water-quality information is to provide a basis on which regional and national-level policy decisions can be based. Wise decisions must be based on sound information. As a society we need to know whether certain types of water-quality problems are isolated or ubiquitous, whether there are significant differences in conditions among regions, whether the conditions are changing over time, and why these conditions change from place to place and over time. The information can be used to hel p determine the efficacy of existing water-quality policies and to help analysts determine the need for, and likely consequences of, new policies.

To address these needs, the Congress appropriated funds in 1986 for the USGS to begin a pilot program in seven project areas to devel op and refine the National Water-Quality Assessment (NAWQA) Program. In 1991, the USGS began full implementation of the program. The NAWQA Program builds upon an existing base of water-quality studies of the USGS, as well as those of other Federal, State, and local agencies. The objectives of the NAWQA Program are to:

- Describe current water-quality conditions for a large part of the Nation's freshwater streams, rivers, and aquifers.

- Describe how water quality is changing over time.

- I mprove understanding of the primary natural and human factors that affect water-quality conditions.

This information will help support the development and evaluation of management, regulatory, and monitoring decisions by other Federal, State, and local agencies to protect, use, and enhance water resources.

The goals of the NAWQA Program are being achieved through ongoing and proposed investigations of 60 of the Nation's most important river basins and aquifer systems, which are referred to as study units. These study units are distributed throughout the Nation and cover a diversity of hydrogeologic settings. More than two-thirds of the Nation's freshwater use occurs within the 60 study units and more than twothirds of the people served by public water-supply systems live within their boundaries.

National synthesis of data analysis, based on aggregation of comparable information obtained from the study units, is a major component of the program. This effort focuses on selected water-quality topics using nationally consistent information. Comparative studies will explain differences and similarities in observed water-quality conditions among study areas and will identify changes and trends and their causes. The first topics addressed by the national synthesis are pesticides, nutrients, volatile organic compounds, and aquatic biology. Discussions on these and other water-quality topics will be published in periodic summaries of the quality of the Nation's ground and surface water as the information becomes available.

This report is an element of the comprehensive body of information developed as part of the NAWQA Program. The program depends heavily on the advice, cooperation, and information from many Federal, State, interstate, Tribal, and local agencies and the public. The assistance and suggestions of all are greatly appreciated.

Robert M. Hirsch

Chief Hydrologist 



\section{CONTENTS}

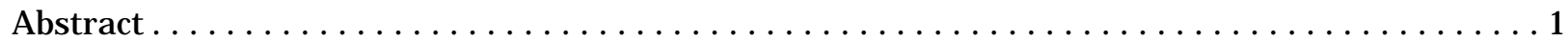

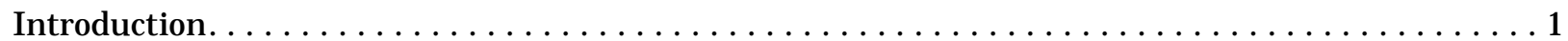

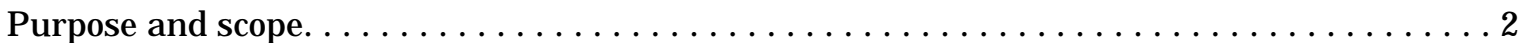

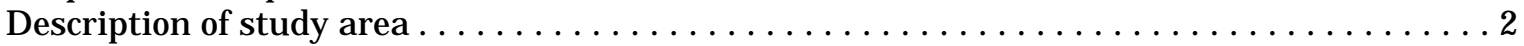

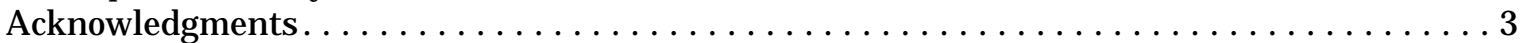

Coal mining in the Allegheny and Monongahela basins $\ldots \ldots \ldots \ldots \ldots \ldots \ldots \ldots \ldots \ldots \ldots \ldots \ldots$

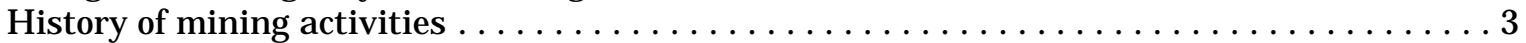

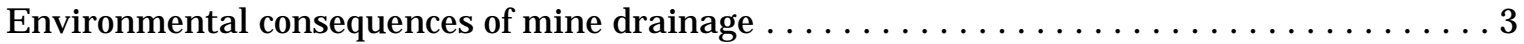

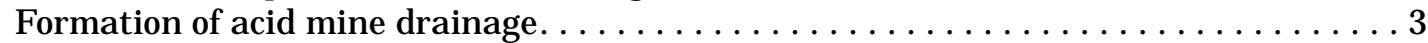

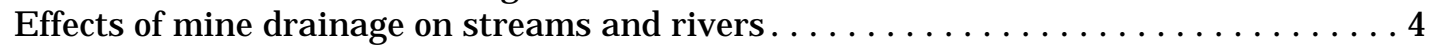

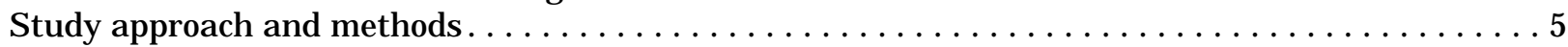

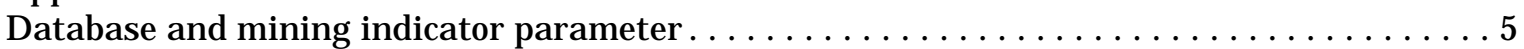

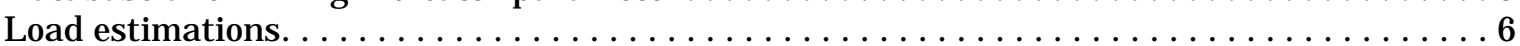

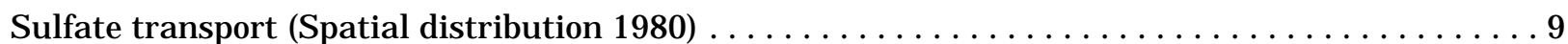

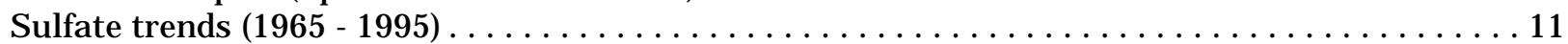

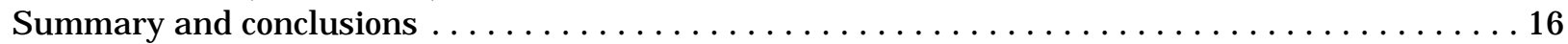

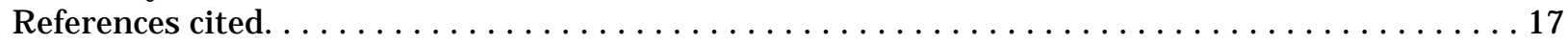

\section{ILLUSTRATIONS}

Figure 1. Map showing location of the study area, major cities, and streams in the Allegheny and Monongahela River Basins ................. 2

2. Photograph of a stream affected by mine drainage in southwestern

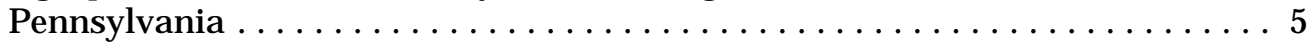

3. Map showing locations of water-quality monitoring sites $\ldots \ldots \ldots \ldots \ldots \ldots \ldots$

4. Boxplots showing concentrations of dissolved sulfate in pre-mining and postmining periods at Stony Fork near Gibbon Glade, Pa. (1977-94) . . . . . . . . . 8

5. Map showing sulfate yiel ds at water-quality-network sites for the 1980 water year.................................. 10

6. Boxplots showing the distribution of sulfate concentrations for selected streams in the Allegheny and Monongahela River Basins, 1965-95 . . . . . . . . 12

7. Map showing trends in sulfateconcentrations for water-quality monitoring sites (1965-95).

8. Graphs showing estimated coal production and sulfate loads for selected coalmined subbasins in the Allegheny and Monongahela River Basins. . . . . . . . 14

9. Graph showing median 5-year sulfate concentrations for the Loyalhanna Creek

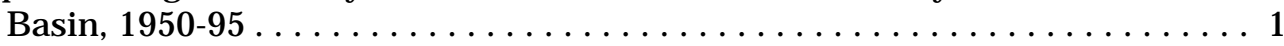




\section{TABLES}

Page

Table 1. Water-quality sites for analysis of mine drainage effects in the Allegheny

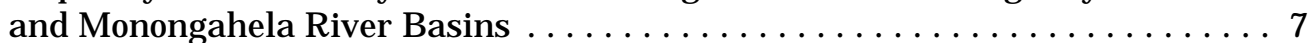

2. Sulfate loads, yields, and percentages for Water Quality Network Stations in the Allegheny and Monongahela River Basins (1980 water year) . . . . . . . 9

3. Data extracted from Geographic I nformation System databases on coal mining for trend sites in the Allegheny and Monongahela River Basins . . . . . 11

4. Trends in sulfate concentrations at water-quality stations in the Allegheny

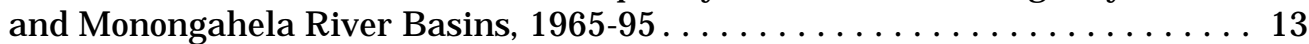

\section{CONVERSION FACTORS AND ABBREVIATIONS}

$\begin{array}{lll}\text { Multiply } & \underline{\text { By }} & \\ & \text { Length } & \\ \text { inch (in) } & 2.54 & \text { centimeter } \\ \text { mile (mi) } & 1.609 & \text { kilometer } \\ & \text { Area } & \\ \text { square mile }\left(\mathrm{mi}^{2}\right) & 2.590 & \text { square kilometer } \\ & \text { Mass } & \\ \text { ton, short }(2,000 \mathrm{lb}) & 0.9072 & \text { megagram } \\ \text { ton per day (ton } / \mathrm{d}) & 0.9072 & \text { metric ton per day } \\ \text { ton per square } \mathrm{mile}\left(\text { ton } / \mathrm{mi}^{2}\right) & 0.3503 & \text { megagram per square kilometer }\end{array}$

Abbreviations water-quality units used in this report: $\mathrm{mg} / \mathrm{L}$, milligrams per liter ton $/ \mathrm{mi}^{2} / \mathrm{yr}$ - ton per square mile per year 


\title{
Effects of CoAl-Mine Drainage ON STREAM Water Quality IN THE AlleghenY AND MonONgahela RIVER BASINS- SULFATE TRANSPORT AND TRENDS
}

\author{
by J ames I. Sams III and Kevin M. Beer
}

\begin{abstract}
In 1980, the Allegheny and Monongahela Rivers transported a sulfate load of 1.2 million and 1.35 million tons, respectively, to the Ohio River at Pittsburgh. The Monongahela River Basin had a sulfate yield of 184 tons per square mile per year compared to 105 tons per square mile per year for the Allegheny River Basin. Within the large Allegheny and Monongahela River Basins, the subbasins with the highest sulfate yields in tons per square mile per year were those of Redstone Creek (580), Blacklick Creek (524), Conemaugh River (292), Buffalo Creek (247), Stonycreek River (239), Two Lick Creek (231), Dunkard Creek (212), and Loyalhanna Creek (196). These basins have been extensively mined. The sulfate yields of Brokenstraw and Conewango Creeks, which are outside the area underlain by coal and thus contain no coal mines, were 25 and 24 tons per square mile per year, respectively.

Within the Allegheny and Monongahela River Basins, seven sites showed significant trends in sulfate concentration from 1965 to 1995. Dunkard Creek and Stonycreek River show significant upward trends in sulfate concentration. These trends appear to be related to increases in coal production in the two basins from 1965 to 1995. Blacklick Creek at J osephine and Loyalhanna Creek at Loyalhanna Dam show significant downward trends in sulfate concentration between 1965 and 1995. Blacklick Creek had a 50-percent decrease in sulfate concentration. Coal production in the Blacklick Creek Basin, which reached its peak at almost 4 million tons per year in the 1940's, dropped to less than 1 million tons per year by 1995. In the Loyalhanna Creek Basin, which had a 41-percent
\end{abstract}

decrease in sulfate concentration, coal-production rates dropped steadily from more than 1.5 million tons per year in the 1940's to less than 200,000 tons per year in 1995.

\section{INTRODUCTION}

The Allegheny and Monongahela River Basins collectively form 1 of 59 study units selected nationwide as part of the U.S. Geological Survey's (USGS) National Water Quality Assessment (NAWQA) Program. The NAWQA Program was developed to provide nationally consistent information on the status and trends of the Nation's water quality in an effort to evaluate past water-quality problems and to provide a base of knowledge for making future water-management decisions. Studies of the hydrologic systems that include parts of most major river basins and aquifer systems (study-unit investigations) are the building blocks of the NAWQA Program. Study units range in size from less than 1,000 to more than $60,000 \mathrm{mi}^{2}$. The NAWQA Program uses a multiscale, integrated, and interdisciplinary approach to water-quality assessment. Studies are designed to examine the physical, chemical, and biological aspects of each basin. Results from these investigations enable the USGS to meet its program goals by describing current water-quality conditions and identifying natural and human factors affecting basin water quality (Hirsch and others, 1988).

One aspect of the NAWQA Program is to analyze existing water-quality conditions throughout the study-unit. Acid mine drainage (AMD) from coal mining has been identified as the factor having the most widespread effect on water quality in the 
Allegheny and Monongahela River Basins

(U.S. Army Corps of Engineers, 1997). Most of the drainage is from abandoned mine sites. Water discharging from deep-mine openings and surfacemine seeps results in el evated concentrations of acidity, iron, manganese, aluminum, and sulfate in receiving streams and rivers. Streams and rivers with low buffer capacity are not able to neutralize the acid load and consequently become acidic. An estimated 2,390 mi of streams in the Allegheny and Monongahela River Basins have been degraded by AMD to the point of not being able to support fish communities (U.S. Environmental Protection Agency, 1995). The AMD problem is a consequence of more than 200 years of coal mining in the study unit. On the basis of current production rates, available coal reserves, and mining economics, coal mining should continue in the Allegheny and Monongahela River Basins well into the next century. For more than two decades, legislation and programs have been in place at the national and state levels to monitor and reduce the effects of coal mining on water quality.

\section{Purpose AND SCOPE}

This report examines sulfate transport and trends as an indicator of drainage from past and present coal mining in the Allegheny and Monongahela River Basins. This report also presents a brief history of coal-mining activities in the study area and a description of the environmental effects associated with mine drainage. A description of the study area and analytical methods used in this investigation are included. To evaluate the spatial distribution of mining effects in the Allegheny and Monongahela River Basins, annual sulfate loads and yields were calculated for 37 water-quality monitoring stations for the 1980 water year. Trends in sulfate loads are presented for 15 of the 37 sites for the period 1965 to 1995. This report will be useful to managers of water resources for evaluating the effects of mining on water quality and evaluating the effectiveness of AMD control measures.

\section{DESCRIPTION OF STUdY AREA}

The Allegheny and Monongahela River Basins are mostly within the Appalachian Plateaus Physiographic Province within the states of New York, Pennsylvania, Maryland, and West Virginia (fig. 1). The total combined drainage area of the Allegheny and Monongahela River Basins is $19,145 \mathrm{mi}^{2}$. The Allegheny River has a length of $295 \mathrm{mi}$; the Monongahela River has a length of $116 \mathrm{mi}$. The Allegheny and Monongahela Rivers join to form the Ohio River at an area in Pittsburgh known as the Point.

The climate in the study area is humid continental, characterized by warm summers and cold winters. Prevailing winds are from the west. Average annual precipitation over the study area is 42 in. and ranges from $37 \mathrm{in}$. in the northern areas to $60 \mathrm{in}$. in the southern mountain areas. Average annual runoff is 18 to $26 \mathrm{in}$. in the northern part of the study area and 25 to $40 \mathrm{in}$. in the southern mountains.

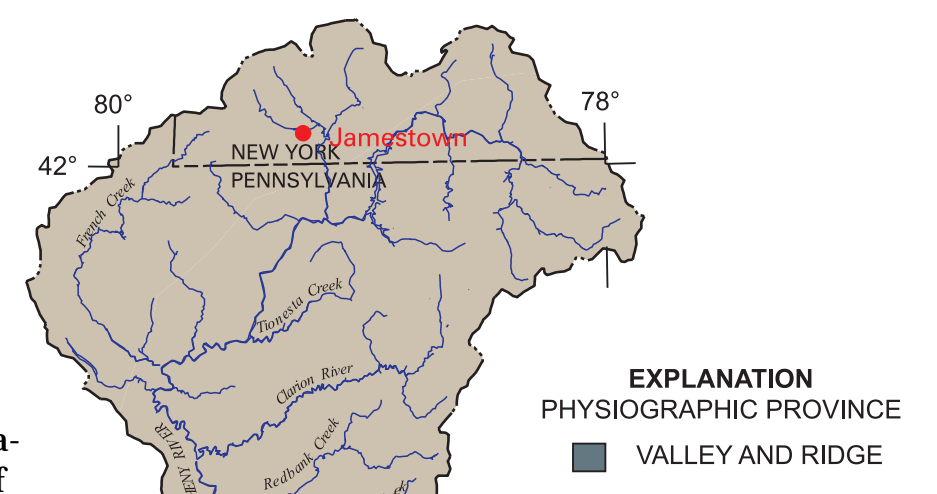


The study area is a mixed land-use type containing about 74 percent forest, 21 percent mixed agriculture, and 2 percent urban. The remaining area consists of open water, wetlands, and barren land (from mining, construction, etc.).

The study area is underlain by sedimentary rocks of Devonian, Mississippian, Pennsylvanian, and Permian age rocks. These rocks are commonly fractured and folded but may also be flat-lying. Bituminous coal is present in the Mississippian, Pennsylvanian, and Permian rocks and underlies approximately 70 percent of the study area.

\section{ACKNOWLEDGMENTS}

The authors wish to thank Michael Langland of the USGS in Lemoyne, Pa., for his assistance in setting up and applying the computer model used to estimate sulfate loads and trends.

\section{COAL MINING IN THE ALLEGHENY AND MONONGAHELA BASINS}

\section{HISTORY OF MINING ACTIVITIES}

Coal has been mined from the Allegheny and Monongahela River Basins for more than 200 years. Early records of coal mining in Pennsylvania are shown on plans of Fort Pitt in 1761. Fort Pitt was located at the confluence of the Allegheny and Monongahela Rivers at present day Pittsburgh. The most significant coal bed in the basin is the Pittsburgh seam, which also is one of the most valuable mineable deposits in the world for its use in the iron and steel industry (Edmunds and Koppe, 1968).

Coal has been central to the economy and lifestyle of many communities in the Allegheny and Monongahela River Basins. More than any other activity, coal mining has influenced growth and development of this region. Beginning in the 1800's, the mining of coal helped fuel an industrial revolution that would make Pittsburgh one of the wealthiest cities in the United States. The mining of coal in western Pennsylvania and the iron and steel manufacturing in Pittsburgh provided thousands of jobs for immigrants to this country. Coal production in Pennsylvania peaked at 177 million tons in 1918, at the height of World War I. In 1920, coal supplied 80 percent of the total United States fuel needs (Western Pennsylvania Conservancy, 1980). The Great Depression of the 1930's began a trend of declining coal production in Pennsylvania. Compet- ing energy sources included fuel oil, natural gas, and nuclear power. In 1974, there was a resurgence in coal mining in Pennsylvania. The increase in production was short lived, however, due in part to the passage of strict environmental laws such as the Federal Surface Mining Control and Reclamation Act of 1977 (P.L. 95-87) (SMCRA) (Pennsylvania Coal Association, 1994). In 1995, Pennsylvania was the fourth largest coal producer in the United States at 69 million tons, behind Wyoming, West Virginia, and Kentucky. Until the late 1940's, most coal had been mined underground using room and pillar methods. But modern earthmoving equipment developed in the late 1940's resulted in an increase in coal mined using surface-mining methods. Drake (1931) reported that streams in the coal regions were being seriously degraded by mine drainage to the point of being unusable for domestic and industrial water supplies.

\section{ENVIRONME NTAL CONSEQUENCES OF MINE DRAINAGE}

\section{Formation of ACID Mine Drainage}

Acid mine drainage (AMD) results from the formation of sulfuric acid in the oxidation of ironsulfide minerals such as pyrite. Pyrite can be found in the coal seam and shale and sandstone strata adjacent to the coal beds. During coal mining, pyrite exposed to air and water oxidizes to form ferrous sulfate and sulfuric acid. The reaction can proceed to produce ferric sulfate, ferric hydroxide, and more sulfuric acid. The following equations show the generally accepted sequence of pyrite reactions (U.S. Office of Surface Mining, 1998a):

$$
\begin{aligned}
& 2 \mathrm{FeS}_{2}+7 \mathrm{O}_{2}+2 \mathrm{H}_{2} \mathrm{O} \rightarrow 2 \mathrm{Fe}^{2+}+4 \mathrm{SO}_{4}{ }^{2-}+4 \mathrm{H}^{+} \\
& 4 \mathrm{Fe}^{2+}+\mathrm{O}_{2}+4 \mathrm{H}^{+} \rightarrow 4 \mathrm{Fe}^{3+}+2 \mathrm{H}_{2} \mathrm{O} \\
& 4 \mathrm{Fe}^{3+}+12 \mathrm{H}_{2} \mathrm{O} \rightarrow 4 \mathrm{Fe}(\mathrm{OH})_{3}+12 \mathrm{H}^{+} \\
& \mathrm{FeS}_{2}+14 \mathrm{Fe}^{3+}+8 \mathrm{H}_{2} \mathrm{O} \rightarrow 15 \mathrm{Fe}^{2+}+2 \mathrm{SO}_{4}{ }^{2-}+16 \mathrm{H}^{+}
\end{aligned}
$$

The AMD chemical reactions produce el evated concentrations of the insoluble precipitate ferric hydroxide $\left[\mathrm{Fe}(\mathrm{OH})_{3}\right]$, dissolved sulfate $\left(\mathrm{SO}_{4}{ }^{2-}\right)$, and acid $\left(\mathrm{H}^{+}\right)$. The pyrite weathering process is a series of chemical reactions but also has an important microbiological component. This reaction can be greatly accelerated by a species of bacteria, Thi obacillus ferroxidans (Singer and Stumm, 1970). Secondary reaction of the sulfuric acid with compounds in adjacent rocks or mine spoil can produce high 
concentrations of aluminum, manganese, zinc, and other constituents in mine drainage waters (Tolar, 1982). As pyrite is oxidized, oxidation products are transported from the oxidation site through subsurface flow systems by ground water or infiltrating precipitation to receiving streams. Acidic water produced by the AMD chemical reactions may persist for only a short time if sufficient alkalinity is available to neutralize the acid. Once the neutralization capacity is exceeded, however, acid begins to accumulate and the $\mathrm{pH}$ decreases.

The watershed represents an integration of many AMD processes throughout the basin. The AMD process consists of three phases: initiation, propagation, and termination. The initiation phase can begin as soon as pyritic materials are exposed to an oxidizing environment; however, the acid load generated is relatively small. In the propagation phase, acid production increases rapidly. In the termination phase, acid production gradually declines. The actual times associated with these phases are uncertain but generally are on the order of years to decades. Modeling predictions and comparison to a limited number of field sites indicate that the acid production peaks 5 to 10 years after mining, followed by a gradual decline over 20 to 40 years (Ziemkiewicz and Meek, 1994).

This cyclic propagation of acid generation takes place very rapidly and continues until the supply of exposed sulfuric material is exhausted. Although natural weathering reduces sulfuric material available for AMD reactions, the opening of new mines and roof falls of old mines create new surfaces for AMD reactions. Other pyrite sources include waste material piled outside of mine openings, refuse piles from preparation plants, and surface-mine overburden that has been backfilled after coal removal.

The geol ogic setting of the mine site is a major factor in post-mining water chemistry. Post-mining water quality can range from alkaline to severely acidic depending on the relative amounts of carbonates and sulfides. Carbonates weather to produce alkalinity. The weathering of sulfides such as pyrite produces acidity. The distribution of carbonates and sulfides throughout the coal regions in this study area is related to the depositional environments in which sediments accumulated. High concentrations of sulfide minerals occur in marine and brackish environments, whereas freshwater deposits frequently contain calcareous minerals. In the coal bearing rocks of western Pennsylvania, the amount of cal careous rocks increase stratigraphically upward from the Pottsville Group (less than 1 percent calcareous rock) to rocks of the Conemaugh group, which can be greater than 50 percent calcareous (Pennsylvania Department of Environmental Protection, 1998). If sufficient carbonate is present, post-mining water quality will be alkaline.

An understanding of mine-site geology, rock composition, and depth of weathering is important in estimating post-mining water qual ity. Changes to the lateral and vertical facies of rock units occur within mine sites and thus require detailed drilling to map these changes. At the watershed scale, many geologic factors influence water quality. It was beyond the scope of this investigation to collect and evaluate geol ogic data.

Since 1979, mining has been regulated by the SMCRA, which has many provisions designed to limit environmental effects from coal mining. The law requires coal operators and state regulatory authorities to evaluate probable hydrol ogic consequences of the mining operation. Methods have been developed to estimate post-mining water quality through chemical analysis of overburden such as acid-base accounting methods (Sobek and others, 1978) This technique is used to identify alkaline and acidic strata. The weight percent of sulfur in stratigraphic layers is measured to estimate the amount of pyritic sulfur and the maximum potential acidity. Since the mid 1980's, practices have been devel oped to handle toxic overburden layers in a special manner to reduce AMD chemical reactions. These advances in mining technol ogy have resulted in a greater percentage of completed coal mines with acceptable post-mining water quality. For example, the Pennsylvania Department of Mining and Reclamation had an average failure rate of 14.7 percent (mine treatment required) for permits issued from 1977 to 1984 compared to a failure rate of 2.9 percent for permits issued from 1985 to 1992 (Pennsylvania Department of Environmental Protection, 1998).

\section{EFFECTS OF Mine DRAINAGE ON STREAMS AND RIVERS}

A study by Williams and others (1996) on 270 mine discharges in the Stonycreek River Basin found that many of the discharges had a pH less than 3.0. Water samples from these discharges generally had high concentrations of acidity, iron, manganese, aluminum, and sulfate. Water quality is thus severely degraded when mine discharges such 
as these enter streams and rivers. A common scene throughout the coal regions of Pennsylvania and West Virginia is shown in figure 2.

AMD can seriously affect aquatic habitats. Stream bottoms covered with orange or yellowbrown iron oxide or white aluminum oxide precipitates can be toxic to benthic algae, invertebrates, and fish. Bottom-dwelling organisms are particularly sensitive to AMD precipitates. Depressed food supplies, gill clogging, and general smothering by iron or aluminum precipitates, along with direct toxicity from ingested metals, contribute to the decline of benthic invertebrates in metal oxide polluted streams (Koryak, 1997).

The effects of AMD on streams have been documented for many years. In 1906, a large fish kill on the Allegheny River below the Kiskiminetas River confluence was caused by AMD (Lewis, 1906). In the

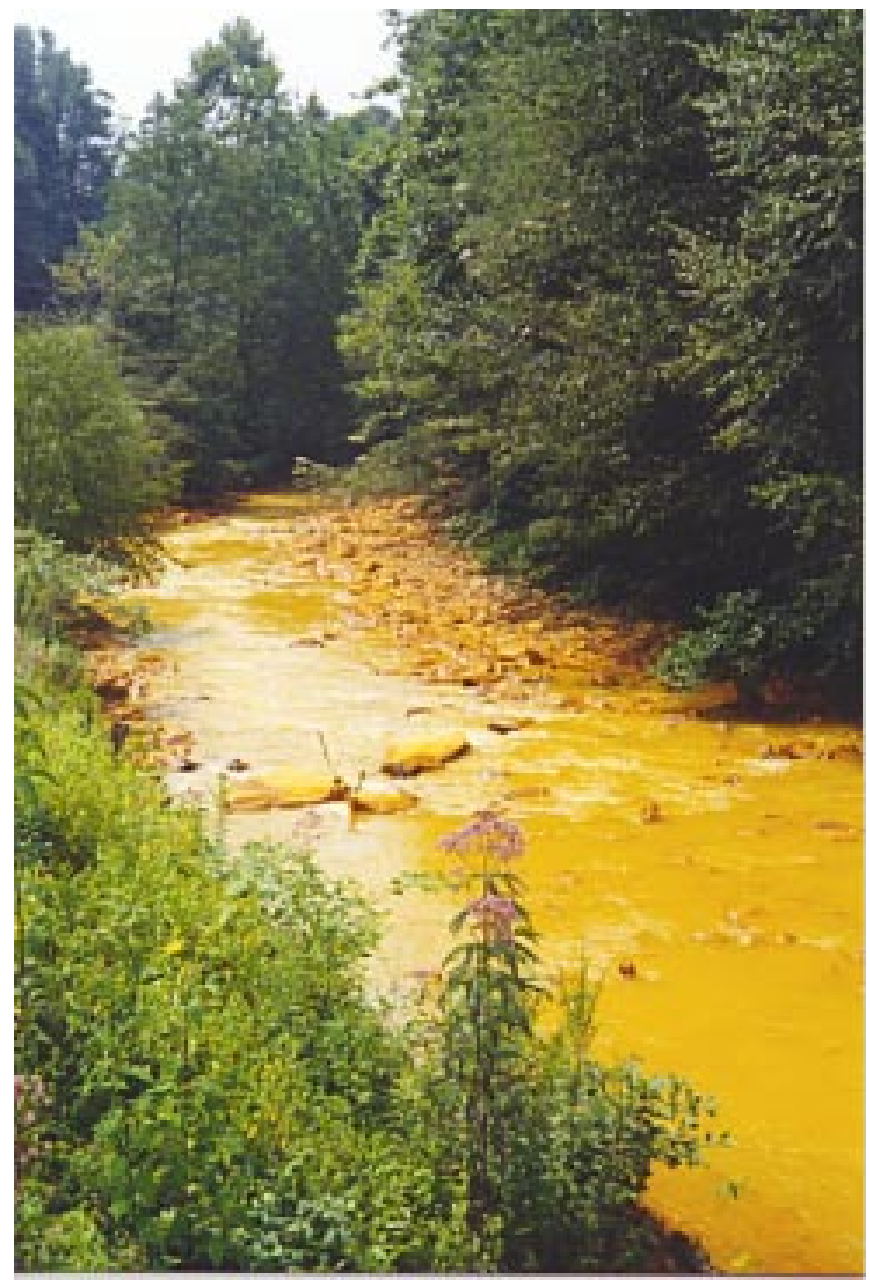

Figure 2. A stream affected by mine drainage in southwestern Pennsylvania. early 1930's, the U.S. Public Health Service designed a program to seal abandoned coal mines in an attempt to prevent AMD formation. Tisdale (1936) reported that 3,644 mine openings had been sealed in West Virginia, which improved water quality in 500 stream miles.

The understanding of mine-site hydrology and the factors affecting water quality has greatly reduced post-mining water-quality problems for recently completed mine sites. However, mine drainage from abandoned mines remains a major problem in streams and rivers in the Allegheny and Monongahela River Basins. The cost to clean up the AMD problem from abandoned mineland sites in Pennsylvania is estimated at 5 billion dollars, and the estimated cost to reclaim all abandoned mineland sites is 15 billion dollars (Pennsylvania Department of Environmental Protection, 1996). Pennsylvania currently receives about 19 million dollars per year from the Federal Office of Surface Mining (OSM) to correct abandoned mine-land problems. Most of this money is spent to correct unsafe conditions such as open mine shafts (U.S. Office of Surface Mining, 1998b).

\section{STUDY APPROACH AND METHODS}

\section{Database And Mining Indicator Parameter}

Sulfate was selected as an indicator of the presence of AMD in streams in the Allegheny and Monongahela River Basins. Sulfate data from water-quality monitoring stations in Pennsylvania and West Virginia were analyzed to evaluate the long-term trends in the effects of coal mining on the streams. These data were retrieved from the USEPA Storage and Retrieval of U.S. Waterways Parametric Data (STORET) database. The monitoring stations were part of the Pennsylvania and West Virginia Water Quality Monitoring Network (WQN) Program. Sites were selected on the basis of the availability of continuous streamflow data. The streamflow data were retrieved from the USGS Water Data Storage and Retrieval System (WATSTORE) database. Sites used in this study are shown on figure 3 and listed in table 1 . The 1980 water year was selected to look at the spatial distribution of mining effects because that year had the greatest number of WQN sites (37) with data between 1965 and 1995. Fifteen of the sites had sulfate and streamflow data from 1965 to 1995. These sites were used to evaluate long-term trends of mine drainage using sulfate as the indicator. 
Sulfate is a conservative compound and therefore a good indicator of the occurrence and intensity of mine drainage. Concentrations of sulfate usually are not high in water draining unmined areas even where pyrite is abundant in the coal and associated strata. As an example, water samples collected from Stony Fork near Gibbon Glade, Pa., from 1978 to 1994 show relatively low concentrations of sulfate prior to 1985, when coal mining began in the basin (fig. 4). The median concentration of sulfate in samples collected after mining began was about five times greater than the median concentration in samples collected before mining. The range in streamflow conditions at the time water samples were collected was similar for preand post-mining periods. As described earlier, the mining process exposes pyrite to weathering, which can release acidity, iron, manganese, aluminum, and sulfate. Although mine drainage may contain elevated concentrations of iron, manganese, and aluminum, these el ements usually are not a reliable indicator of AMD because they may not remain in solution. Sulfate, however, is an excellent indicator of mine drainage because the sulfate ion is very soluable and chemically stable at the $\mathrm{pH}$ levels normally encountered in natural waters (Hem, 1985). The treatment of mine drainage to remove metals and neutralize acidity has little or no effect on sulfate concentration (Keith Brady, Pennsylvania Department of Environmental Protection, oral commun., 1997).

\section{LOAD ESTIMATIONS}

Annual sulfate loads were computed from sulfate concentration data by use of a 7-parameter log-linear multiple regression model, known as Estimator, which was developed by Cohn and others (1989). The model was validated by Cohn and others (1992) with repeated split-sample studies and is currently used at nine monitoring stations for the Chesapeake Bay Nutrient Monitoring Program (Maryland Department of the Environment, 1992). The model is devel oped from measured

Base from U.S. Geological Survey $1: 2,000,000$ and $1: 100,000$ Digital Data

Figure 3. Locations of water-quality monitoring sites. streamflow and concentration data. Continuous

$$
\ln [C]=\beta_{o}+\beta_{1} \ln [Q / \bar{Q}]+\beta_{2} \ln \{[Q / \bar{Q}]\}^{2}+\beta_{3}[T-\bar{T}]+\beta_{4}[T-\bar{T}]^{2}+\beta_{5} \sin [2 \pi T]+\beta_{6} \cos [2 \pi T]+\varepsilon
$$


Table 1. Water-quality sites for analysis of mine drainage effects in the Allegheny and Monongahela River Basins

\begin{tabular}{|c|c|c|c|}
\hline SITE & $\begin{array}{l}\text { DRAINAGE } \\
\text { AREA } \\
\text { (SQUARE } \\
\text { MILES) }\end{array}$ & $\begin{array}{l}\text { U.S. GEOLOGICAL } \\
\text { SURVEY SITE } \\
\text { IDENTIFICATION } \\
\text { NUMBER }\end{array}$ & $\begin{array}{l}\text { STATE WATER } \\
\text { QUALITY NETWORK } \\
\text { IDE NTIFICATION } \\
\text { NUMBER }\end{array}$ \\
\hline \multicolumn{4}{|c|}{ Allegheny River Basin } \\
\hline Potato Creek at Smethport, Pa. & 160 & 03009680 & WQN0856 \\
\hline Allegheny River at Eldred, $\mathrm{Pa}$. & 550 & 03010500 & WQN 0807 \\
\hline Kinzua Creek near Guffey, Pa. & 46 & 03011800 & WQN 0855 \\
\hline Conewango Creek at Russell, Pa. & 816 & 03015000 & WQN0832 \\
\hline Brokenstraw Creek at Youngsville, Pa. & 321 & 03015500 & WQN0831 \\
\hline Allegheny River at West Hickory, Pa. & 3,660 & 03016000 & WQN0805 \\
\hline French Creek at Utica, Pa. & 1,028 & 03024000 & WQN0826 \\
\hline Allegheny River at Franklin, $\mathrm{Pa}$. & 5,982 & 03025500 & WQN 0804 \\
\hline West Branch Clarion River at Wilcox, Pa. & 63 & 03028000 & WQN0824 \\
\hline Clarion River at Cooksburg, Pa. & 807 & 03029500 & WQN0822 \\
\hline Clarion River near Piney, Pa. & 951 & 03030500 & WQN0821 \\
\hline Allegheny River at Parker, Pa. & 7,671 & 03031500 & WQN0803 \\
\hline Redbank Creek at St. Charles, Pa. & 528 & 03032500 & WQN 0820 \\
\hline Allegheny River at Kittanning, $\mathrm{Pa}$. & 8,973 & 03036500 & WQN 0802 \\
\hline Stonycreek River at Ferndale, $\mathrm{Pa}$. & 451 & 03040000 & WQN0817 \\
\hline Conemaugh River at Seward, Pa. & 715 & 03041500 & WQN0811 \\
\hline Blacklick Creek at J osephine, Pa. & 192 & 03042000 & WQN 0814 \\
\hline Two Lick Creek at Graceton, Pa. & 171 & 03042500 & WQN0815 \\
\hline Loyalhanna Creek at Kingston, Pa. & 172 & 03045000 & WQN 0813 \\
\hline Loyalhanna Creek at Loyalhanna Dam, Pa. & 292 & 03047000 & WQN 0812 \\
\hline Buffalo Creek near Freeport, Pa. & 137 & 03049000 & WQN0808 \\
\hline Allegheny River at New Kensington, Pa. & 11,410 & 03049500 & 03049625 \\
\hline \multicolumn{4}{|c|}{ Monongahela River Basin } \\
\hline Buckhannon River at Hall, W. Va. & 277 & 03053500 & 550796 \\
\hline Tygart Valley River at Philippi, W. Va. & 916 & 03054500 & 550822 \\
\hline Tygart Valley River at Colfax, W. Va. & 1,366 & 03057000 & 550574 \\
\hline Dry Fork at Hendricks, W. Va. & 345 & 03065000 & 550851 \\
\hline Shavers Fork at Parsons, W. Va. & 214 & 03069000 & 550486 \\
\hline Dunkard Creek at Shannopin, Pa. & 229 & 03072000 & WQN 0714 \\
\hline Monongahela River at Greensboro, Pa. & 4,407 & 03072500 & WQN0703 \\
\hline South Fork Tenmile Creek at J efferson, Pa. & 180 & 03073000 & WQN0713 \\
\hline Redstone Creek at Waltersburg, Pa. & 74 & 03074500 & WQN 0712 \\
\hline Casselman River at Grantsville, Md. & 63 & 03078000 & CAS0479 \\
\hline Casselman River at Markleton, $\mathrm{Pa}$. & 382 & 03079000 & WQN0710 \\
\hline Laurel Hill Creek at Ursina, Pa. & 121 & 03080000 & WQN0724 \\
\hline Youghiogheny River at Connellsville, Pa. & 1,326 & 03082500 & WQN0707 \\
\hline Youghiogheny River at Sutersville, Pa. & 1,715 & 03083500 & WQN0706 \\
\hline Monongahela River at Braddock, Pa. & 7337 & 03085000 & 03085000 \\
\hline
\end{tabular}

where In is the natural logarithm function;

$\mathrm{C}$ is measured concentration of the constituent of interest, in milligrams per liter;

$\mathrm{Q}$ is measured streamflow, in cubic feet per second;

T is time, measured in decimal years;

$\bar{Q}$ and $\bar{T}$ are centering variables for streamflow and time;

$\beta_{x}$ are parameters estimated by ordinary least squares; and

$\varepsilon$ is combined independent random error, assumed to be normally distributed with zero mean and variance $\sigma_{\varepsilon}^{2}$. 


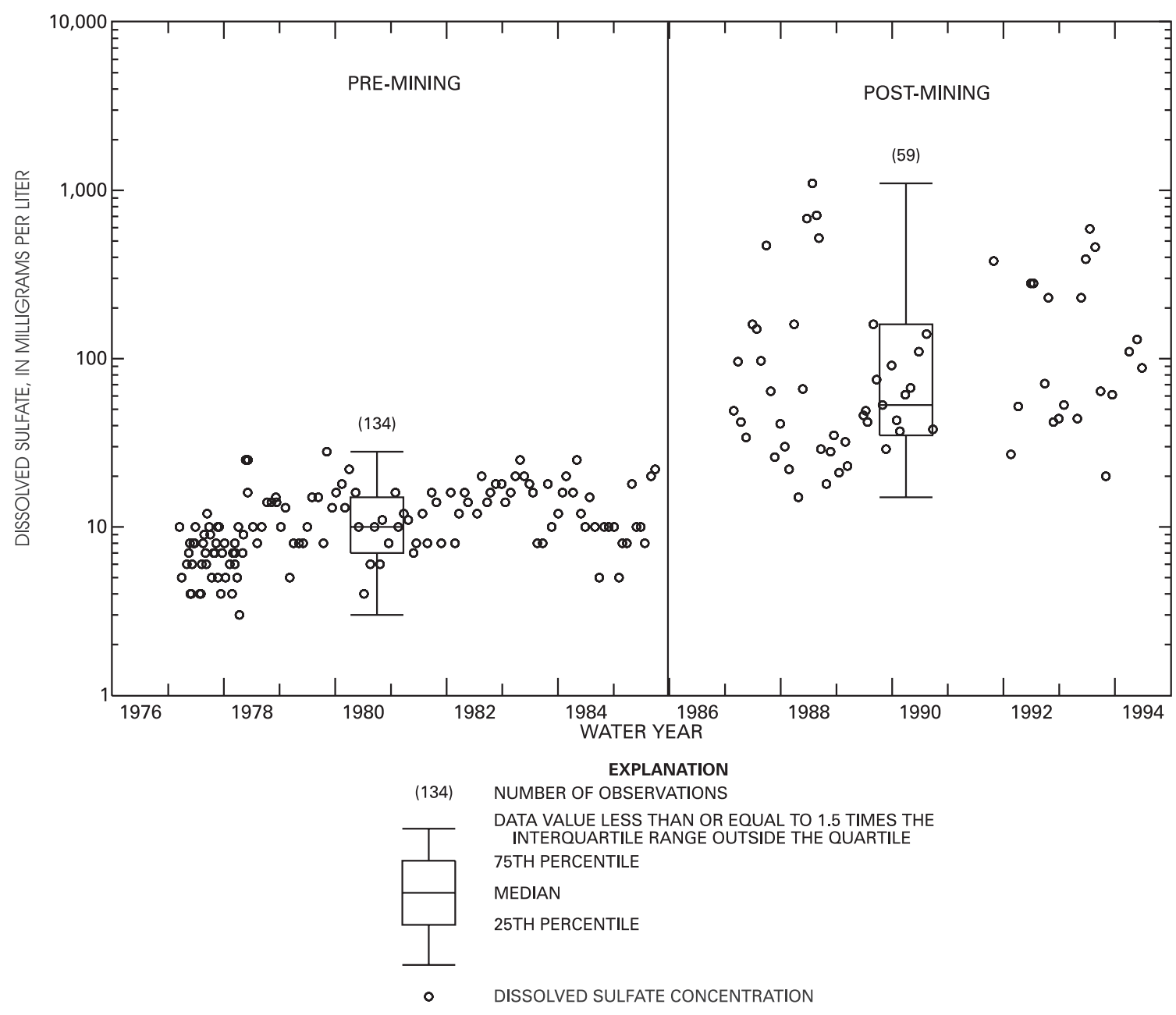

Figure 4. Concentrations of dissolved sulfate in pre-mining and post-mining periods at Stony Fork near Gibbon Glade, Pa. (1977-94).

Mean daily concentrations predicted by the model are combined with mean daily streamflow to calculate daily loads as follows:

$$
L_{T}=\sum_{t=1}^{T}\left\{C_{i, t} \times Q_{t} \times K\right\},
$$

where $L_{T}$ is calculated load over time interval $T$ for constituent $i$;

$\mathrm{C}_{\mathrm{i}, \mathrm{t}}$ is predicted concentration of constituent i for day $\mathrm{t}$, in milligrams per liter (calculated by the model); $\mathrm{Q}_{\mathrm{t}}$ is measured mean daily streamflow for day $\mathrm{t}$, in cubic feet per second; and

$\mathrm{K}$ is conversion factor $2.699 \times 10^{-3} \frac{\mathrm{s} \times \mathrm{L} \times \text { ton }}{\mathrm{ft}^{3} \times \mathrm{mg} \times \mathrm{d}}$, where $\mathrm{s}$ is seconds, $\mathrm{L}$ is liters, ton is tons, $\mathrm{ft}^{3}$ is cubic feet, $\mathrm{mg}$ is milligrams, and $\mathrm{d}$ is days.

(The model usually reports estimated loads in kilograms per day; for this study, the K listed above converts kilograms per day to tons per day.) 


\section{SULFATE TRANSPORT (SPATIAL DISTRIBUTION 1980)}

During 1980, the Allegheny and Monongahela Rivers transported a sulfate load of 1.2 million and 1.35 million tons, respectively, to the Ohio River at Pittsburgh (table2). The Monongahela River Basin, although smaller in drainage area $\left(7,337 \mathrm{mi}^{2}\right)$ compared to the Allegheny River Basin $\left(11,410 \mathrm{mi}^{2}\right)$, contributed 53 percent of the sulfate load to the Ohio River at Pittsburgh in 1980.

Fifty-five percent $(661,800$ tons) of the total sulfate load of the Allegheny River enters the river above the WQN site at Kittanning (table 2). The Allegheny River at Parker transported 270,200 tons and Redbank Creek at St. Charles transported 61,480 tons for a combined total of 331,680 tons, or 50 percent of the sulfate load at Kittanning. The remaining sulfate load bel ow Parker and above Kittanning likely enters the Allegheny River from mine-drainage sources on Mahoning Creek, lower sections of Redbank Creek bel ow St. Charles, or from small streams and tributaries between Parker and Kittanning. The Kiskiminetas River enters the Allegheny River about 15 mi below Kittanning. Sulfate transport within the Kiskiminetas River from

Table 2. Sulfate loads, yields, and percentages for Water Quality Network Stations in the Allegheny and Monongahela River Basins (1980 water year)

\begin{tabular}{|c|c|c|c|c|c|}
\hline STATION NAME & $\begin{array}{l}\text { SULFATE LOAD } \\
\text { (TONS) }\end{array}$ & RANK & $\begin{array}{l}\text { SULFATE YIELD } \\
\text { (TONS PER } \\
\text { SQUARE MILE) }\end{array}$ & RANK & $\begin{array}{c}\text { Percentage } \\
\text { OF TOTAL SULFATE } \\
\text { LOAD AT OUTFLOW }\end{array}$ \\
\hline \multicolumn{6}{|c|}{ Allegheny Basin } \\
\hline Potato Creek at Smethport, Pa. & 2,555 & 20 & 16 & 21 & 0.21 \\
\hline Allegheny River at EIdred, Pa. & 8,961 & 18 & 16 & 20 & .75 \\
\hline Kinzua Creek near Guffey, Pa. & 794 & 22 & 17 & 19 & .07 \\
\hline Conewango Creek at Russell, Pa. & 19,420 & 16 & 24 & 16 & 1.62 \\
\hline Brokenstraw Creek at Youngsville, Pa. & 8,050 & 19 & 25 & 15 & .67 \\
\hline Allegheny River at West Hickory, Pa. & 70,360 & 9 & 19 & 18 & 5.85 \\
\hline French Creek at Utica, $\mathrm{Pa}$ & 31,690 & 15 & 31 & 14 & 2.64 \\
\hline Allegheny River at Franklin, Pa. & 115,400 & 5 & 19 & 17 & 9.60 \\
\hline West Branch Clarion River at Wilcox, Pa. & 888 & 21 & 14 & 22 & .07 \\
\hline Clarion River at Cooksburg, $\mathrm{Pa}$. & 39,400 & 13 & 49 & 12 & 3.28 \\
\hline Clarion River near Piney, Pa. & 91,110 & 8 & 96 & 9 & 7.58 \\
\hline Allegheny River at Parker, Pa. & 270,200 & 3 & 35 & 13 & 22.48 \\
\hline Redbank Creek at St. Charles, Pa. & 61,480 & 10 & 116 & 7 & 5.11 \\
\hline Allegheny River at Kittanning, $\mathrm{Pa}$. & 661,800 & 2 & 74 & 10 & 55.06 \\
\hline Stonycreek River at Ferndale, Pa. & 107,800 & 6 & 239 & 4 & 8.97 \\
\hline Conemaugh River at Seward, Pa. & 208,600 & 4 & 292 & 2 & 17.35 \\
\hline Blacklick Creek at J osephine, Pa. & 100,600 & 7 & 524 & 1 & 8.37 \\
\hline Two Lick Creek at Graceton, Pa. & 39,540 & 12 & 231 & 5 & 3.29 \\
\hline Loyalhanna Creek at Kingston, Pa. & 9,256 & 17 & 54 & 11 & .77 \\
\hline Loyalhanna Creek at Loyalhanna Dam, Pa. & 57,220 & 11 & 196 & 6 & 4.76 \\
\hline Buffalo Creek near Freeport, Pa. & 33,845 & 14 & 247 & 3 & 2.82 \\
\hline Allegheny River at New Kensington, $\mathrm{Pa}$. & $1,202,000$ & 1 & 105 & 8 & 100.00 \\
\hline \multicolumn{6}{|c|}{ Monongahela Basin } \\
\hline Buckhannon River at Hall, W. Va. & 21,300 & 11 & 77 & 8 & 1.58 \\
\hline Tygart Valley River at Philippi, W. Va. & 61,630 & 6 & 67 & 10 & 4.57 \\
\hline Tygart Valley River at Colfax, W. Va. & 93,120 & 4 & 68 & 9 & 6.90 \\
\hline Dry Fork at Hendricks, W. Va. & 39,700 & 9 & 115 & 5 & 2.94 \\
\hline Shavers Fork at Parsons, W. Va. & 6,462 & 13 & 30 & 15 & .48 \\
\hline Dunkard Creek at Shannopin, Pa. & 48,450 & 7 & 212 & 2 & 3.59 \\
\hline Monongahela River at Greensboro, Pa. & 853,300 & 2 & 194 & 3 & 63.21 \\
\hline South Fork Tenmile Creek at J efferson, Pa. & 11,370 & 12 & 63 & 12 & .84 \\
\hline Redstone Creek at Waltersburg, Pa. & 42,750 & 8 & 580 & 1 & 3.17 \\
\hline Casselman River at Grantsville, Md. & 2,911 & 15 & 47 & 13 & .22 \\
\hline Casselman River at Markleton, $\mathrm{Pa}$. & 37,300 & 10 & 98 & 7 & 2.76 \\
\hline Laurel Hill Creek at Ursina, Pa. & 4,248 & 14 & 35 & 14 & .31 \\
\hline Youghiogheny River at Connellsville, Pa. & 85,110 & 5 & 64 & 11 & 6.30 \\
\hline Youghiogheny River at Sutersville, Pa. & 184,400 & 3 & 108 & 6 & 13.66 \\
\hline Monongahela River at Braddock, $\mathrm{Pa}$. & $1,350,000$ & 1 & 184 & 4 & 100.00 \\
\hline
\end{tabular}


Blacklick Creek, Conemaugh River, Stonycreek River, Two Lick Creek, and Loyalhanna Creek accounted for 43 percent of the total sulfate load transported to the Allegheny River at New Kensington for 1980. The U.S. Department of Interior (1967) noted that the Kiskiminetas River discharged massive amounts of acidity (494 ton/d) into the Allegheny River, that the average manganese concentration was $23.2 \mathrm{mg} / \mathrm{L}$, and that the $\mathrm{pH}$ ranged from 3.0 to 3.6. The study estimated about $485 \mathrm{mi}$ of streams within the Kiskiminetas River Basin are affected by mine drainage.

More than 60 percent of the total sulfate load enters the Monongahela River above Greensboro, $\mathrm{Pa}$., which is just downstream of the mouth of Dunkard Creek (table 2, fig. 3). The Monongahela River at Greensboro includes all the Monongahela drainage within West Virginia and the Dunkard Creek drainage area. About 68 percent of the sulfate load is not accounted for at Greensboro on the basis of the sum of the available WQN stations used in this study. Of the 853,300 tons of sulfate transported past Greensboro for the 1980 water year, only 270,000 tons are accounted for by summing all of the available WQN stations upstream. Thus, a significant amount of sulfate enters the Monongahela River either directly from mine discharges or from streams not included in the WQN sites. The U.S. Department of Interior study (1967) noted that streams severely affected by mine drainage enter the Monongahela River above Greensboro and include the West Fork River (acid load of 156 ton/d) and the Cheat River (acid load 204 ton/d). Smaller tributary streams between Fairmont and Morgantown, such as Buffalo Creek, Paw Paw Creek, Scotts Run, and Deckers Creek, contribute significant amounts of mine drainage to the Monongahela River. Downstream of Greensboro, Redstone Creek and South Fork Tenmile Creek contribute a combined total of 54,120 tons of sulfate, or about 4 percent of the total sulfate load to the Monongahela River (table 2). The Youghiogheny River, which enters the Monongahela River about 10 mi upstream of the Allegheny and Monongahela River confluence, contributed 184,400 tons or 14 percent of the sulfate load to the Monongahela River (table 2).
To compare sulfate loads transported by rivers and streams with different drainage areas, the sulfate load was normalized to the drainage area (table 2, fig. 5). The result is a sulfate yield, expressed as tons per square mile. The Monongahela River Basin had a sulfate yield of $184 \mathrm{ton} / \mathrm{mi}^{2} / \mathrm{yr}$ compared to $105 \mathrm{ton} / \mathrm{mi}^{2} / \mathrm{yr}$ for the Allegheny River Basin. Redstone Creek, Blacklick Creek, Conemaugh River, Buffalo Creek, Stonycreek River, Two Lick Creek, Dunkard Creek, and Loyal hanna Creek had the highest sulfate yields of all tributary streams in the study area (table 2). These basins have been extensively mined. Brokenstraw Creek and Conewango Creek, which are outside the coal extent (fig. 5) and contain no coal

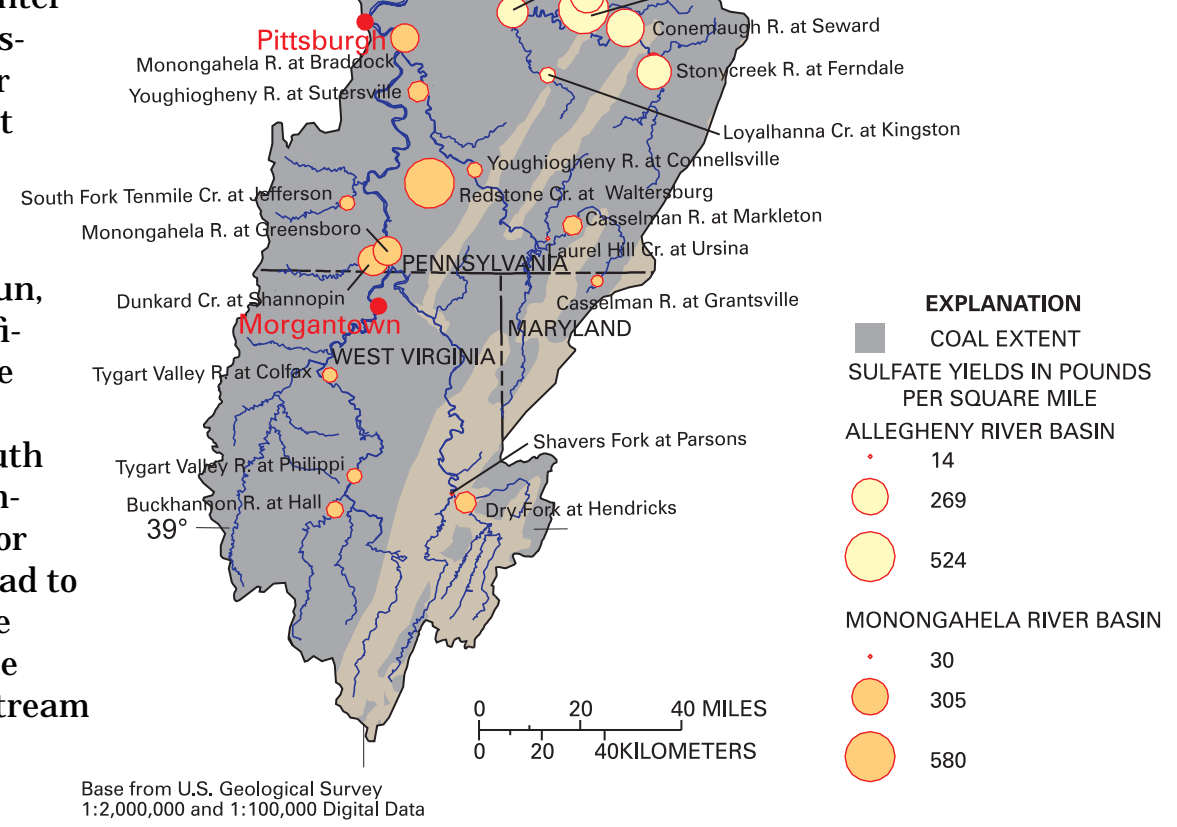

Figure 5. Sulfate yields at water-quality-network sites for the 1980 water year. 
mines, transported sulfate yields of 25 and $24 \mathrm{ton} / \mathrm{mi}^{2} / \mathrm{yr}$, respectively. In a 1967 study, Blacklick Creek was identified as being one of the most mine-affected streams in the Allegheny River Basin with a stream pH below 3.0 (U.S. Department of Interior, 1967). The same study also identified Stonycreek River, Two Lick Creek, Conemaugh River, Loyalhanna Creek, Redstone Creek, and Dunkard Creek as streams severely affected by mine drainage.

\section{SULFATE TRENDS (1965 - 1995)}

A more detailed analysis was conducted on 15 of the 37 sites listed in table 3 to examine long-term trends in sulfate and their relation to coal mining. The sites were selected on the basis of the availability of long-term (1965-95) sulfate concentration and streamflow data. A Geographic Information System (GIS) was used to evaluate the extent of mining activities and mining effects in each of the 15 basins. A summary of available GIS data for the basins is shown on table 3 .

The greatest range and largest maximum concentration of sulfate were in samples collected from streams in basins with extensive coal mining (fig. 6). The largest median concentrations of total sulfate were in samples collected from the mined basins of Blacklick Creek, Dunkard Creek, and Stonycreek River at 241, 234, and $181 \mathrm{mg} / \mathrm{L}$, respectively. Samples collected from the Monongahela River at Braddock had a median sulfate concentration of $110 \mathrm{mg} / \mathrm{L}$ for the period 1965 to 1995. This is almost twice as high as the median concentration of $60 \mathrm{mg} / \mathrm{L}$ for samples collected from the Allegheny River at $\mathrm{N}$ ew Kensington. On the basis of the available GIS data, approximately 6,564 coal mines have operated within the Monongahela River Basin compared to 2,537 coal mines in the Allegheny River Basin. The Monongahela River Basin contains 2,685 abandoned mines and the Allegheny River Basin has 910 abandoned mines. Coal mining and AMD have resulted in $1,071 \mathrm{mi}$ of streams classified with a no-fish designation in the Monongahela River Basin, and 1,320 stream miles so designated in the Allegheny River Basin (table 3).

The Estimator model (Cohn and others, 1989) was used to estimate trends in sulfate concentration through flow and seasonally adjusted raw sulfate concentrations. In this section of the report, trends in sulfate concentration refer to trend in "flow and seasonally adjusted" sulfate concentration, which is synomous with trends in sulfate loads as far as the magnitude and direction. Trends were

Table 3. Data extracted from Geographic I nformation System databases on coal mining for trend sites in the All egheny and Monongahel a River Basins

\begin{tabular}{|c|c|c|c|c|c|}
\hline Site NAME & $\begin{array}{c}\text { MEDIAN SULFATE } \\
\text { CONCENTRATION } \\
\text { IN 1965-95 } \\
\text { (MILLIGRAMS PER LITER) }\end{array}$ & $\begin{array}{c}\text { PRE-1980 } \\
\text { COAL MINE SITES } \\
\text { WITHIN BASIN }\end{array}$ & $\begin{array}{c}1980-95 \\
\text { COAL MINE SITES } \\
\text { WITHIN BASIN }{ }^{2}\end{array}$ & $\begin{array}{l}\text { NUMBER OF } \\
\text { ABANDONED } \\
\text { MINE LANDS } \\
\text { WITHIN BASIN }\end{array}$ & $\begin{array}{l}\text { TOTAL NUMBER } \\
\text { OF STREAM MILES } \\
\text { WITH NO-FISH } \\
\text { DESIGNATION }^{4}\end{array}$ \\
\hline \multicolumn{6}{|c|}{ Allegheny River Basin } \\
\hline Allegheny River at Eldred, Pa. & 12 & $\overline{0}$ & 0 & 7 & 13 \\
\hline Conewango Creek at Russell, $\mathrm{Pa}$. & 20 & 0 & 0 & 0 & 0 \\
\hline Brokenstraw Creek at Youngsville, Pa. & 19 & 0 & 0 & 0 & 0 \\
\hline Allegheny River at West Hickory, Pa. & 16 & 0 & 2 & 10 & 13 \\
\hline Clarion R.iver at Cooksburg, Pa. & 38 & 48 & 31 & 27 & 165 \\
\hline Redbank Creek at St. Charles, Pa. & 94 & 66 & 72 & 71 & 178 \\
\hline Allegheny River at Kittanning, Pa. & 38 & 351 & 259 & 405 & 864 \\
\hline Stonycreek River at Ferndale, Pa. & 181 & 400 & 87 & 107 & 101 \\
\hline Blacklick Creek at J osephine, Pa. & 241 & 207 & 12 & 31 & 43 \\
\hline Loyalhanna Creek Loyalhanna Dam, Pa. & 136 & 78 & 13 & 67 & 40 \\
\hline Allegheny River at New Kensington, Pa. & 60 & 1,982 & 555 & 910 & 1,320 \\
\hline \multicolumn{6}{|c|}{ Monongahela River Basin } \\
\hline Dunkard Creek at Shannopin, Pa. & 234 & 48 & 22 & 4 & 2 \\
\hline Casselman River at Markleton, $\mathrm{Pa}$. & 90 & 81 & 40 & 89 & 99 \\
\hline Youghiogheny River at Sutersville, Pa. & 76 & 379 & 128 & 276 & 226 \\
\hline Monongahela River at Braddock, $\mathrm{Pa}$. & 110 & 5,958 & 606 & 2,685 & 1,071 \\
\hline
\end{tabular}

\footnotetext{
${ }^{1}$ Data from U.S. Office of Surface Mining.

2 Data from U.S. Geological Survey.

${ }^{3}$ Data from U.S. Office of Surface Mining.

${ }^{4}$ Data from U.S. Environmental Protection Agency.
} 


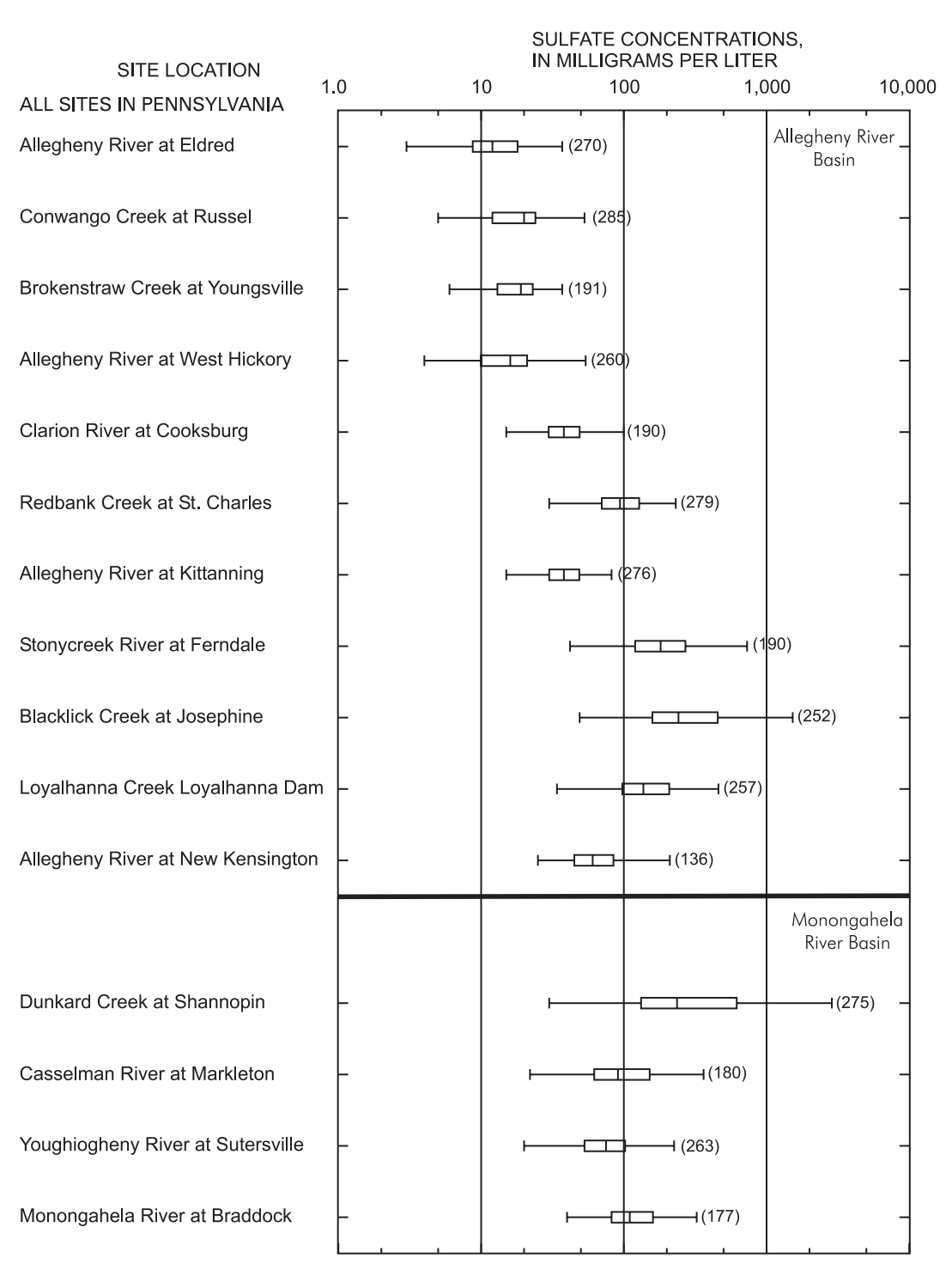

EXPLANATION

DATA VALUE LESS THAN OR EQUAL TO 1.5 TIMES THE INTERQUARTILE RANGE OUTSIDE THE QUARTILE

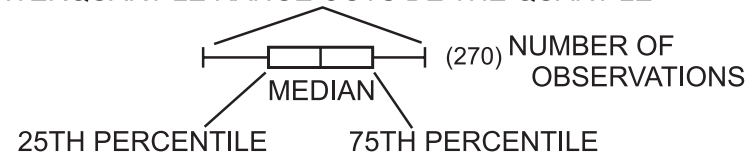

Figure 6. Distribution of sulfate concentrations for selected streams in the Allegheny and Monongahela River Basins, 1965-95. estimated for the period 1965 through 1995 for 11 sites in the Allegheny River Basin and 4 sites in the Monongahela River Basin (table 4, fig. 7). A p-value of less than 0.05 (table 4) indicates a significant trend (95-percent confidence level). The trend direction and magnitude (percent change in trend) are re-transformed from log space. The magnitude of change for the period is determined from the equation:

[exp(B3 t) -1]*100,

where B3 is the DECTIME regression coefficient from the Estimator model and $t$ is the number of years for the time period examined.

Within the Allegheny and Monongahela River Basins, seven sites showed statistically significant trends in sulfate concentration between 1965 and 1995. For four of the sites, the sulfate trend is upward; for three of the sites, the trend is downward.

At two of the sites, Dunkard Creek and Stonycreek River, the trends appear to be related to increases in coal production in the basins from 1965 to 1995 (fig. 8). Coal production was estimated from countybased data for each basin (Pennsylvania Coal Association, 1995; West Virginia Office of Miners' Health Safety and Training, 1997). Coal production in the Dunkard Creek Basin, which averaged about 6.3 million tons between 1945 and 1980, began to steadily increase to 13.7 million tons in 1995. From 1965 to 1995, sulfate concentrations increased 38 percent in the Dunkard Creek Basin. Stonycreek River Basin, which had a 31-percent increase in sulfate concentration, had coal-production rates increasing from a low of 2.1 million tons per year in 1960 to a high of 6.5 million tons per year in 1981. Coal production and annual sulfate loads in the Stonycreek River Basin are somewhat cyclical from 1982 to 1995; however, the overall trend is upward for the period 1965 to 1995. 
Table 4. Trends in sulfate concentrations at water-quality stations in the Allegheny and Monongahela River Basins, 1965-95 [Gray-shaded sites are significant at the 95-percent confidence level]

\begin{tabular}{|c|c|c|c|c|c|}
\hline \multirow{2}{*}{ STATION NAME } & \multirow{2}{*}{$\begin{array}{l}\text { DIRECTION } \\
\text { OF TREND }\end{array}$} & \multicolumn{3}{|c|}{ Percentage change } & \multirow{2}{*}{ P-VALUE } \\
\hline & & MINIMUM & Predicted & MAXIMUM & \\
\hline \multicolumn{6}{|c|}{ Allegheny River Basin } \\
\hline Allegheny River at EIdred & & -2 & 27 & 64 & 0.0655 \\
\hline Conewango Creek at Russell & & -7 & 16 & 44 & .1821 \\
\hline Brokenstraw Creek at Youngsville & Up & 11 & 34 & 62 & .0025 \\
\hline Allegheny River at West Hickory & & -5 & 20 & 51 & .1115 \\
\hline Clarion River at Cooksburg & & -21 & -9 & 4 & .1365 \\
\hline Redbank creek at St. Charles & & -3 & 19 & 46 & .0903 \\
\hline Allegheny River at Kittanning & Up & 3 & 23 & 48 & .0273 \\
\hline Stonycreek River at Ferndale & Up & 0 & 31 & 72 & .0482 \\
\hline Blacklick Creek at J osephine & Down & -61 & -50 & -35 & 0 \\
\hline Loyalhanna Creek at Loyalhanna Dam & Down & -52 & -41 & -29 & 0 \\
\hline Allegheny River at New Kensington & & -33 & -14 & 9 & .2037 \\
\hline \multicolumn{6}{|c|}{ Monongahela River Basin } \\
\hline Dunkard Creek at Shannopin & Up & 8 & 38 & 78 & .0105 \\
\hline Casselman River at Markleton & & -8 & 12 & 36 & .2338 \\
\hline Youghiogheny River at Sutersville & & -24 & -12 & 0 & .0566 \\
\hline Monongahela River at Braddock & Down & -40 & -24 & -4 & .0173 \\
\hline
\end{tabular}

Blacklick Creek at J osephine and Loyalhanna Creek at Loyalhanna Dam show statistically significant downward trends in sulfate concentrations between 1965 and 1995. Blacklick Creek had a 50-percent decrease in sulfate concentration. Coal production in the Blacklick Creek Basin, which reached its peak at 3.5 million tons per year in the 1940's, decreased to less than 1 million tons per year by 1995. Loyalhanna Creek Basin, which had a 41-percent decrease in sulfate concentration, had coal production rates decline steadily from more than 1.5 million tons per year in the 1940's to less than 200,000 tons per year in 1995.

The sulfate concentrations of Brokenstraw Creek at Youngsville increased 34 percent over the 30-year period. Because Brokenstraw Creek Basin was not mined, atmospheric deposition is considered a possible cause of this increase. However, sulfate concentrations in precipitation in the Eastern United States from 1983 to 1994 indicate a downward trend. Lynch and others (1996) attribute this trend, along with increases in $\mathrm{pH}$, to passage of the Phase I Clean Air Act Amendments of 1990 (Public Law 101-549). Even so, the northern part of the Allegheny River Basin receives some of the highest sulfate deposition in the United States (National Atmospheric Deposition Program, 1998).

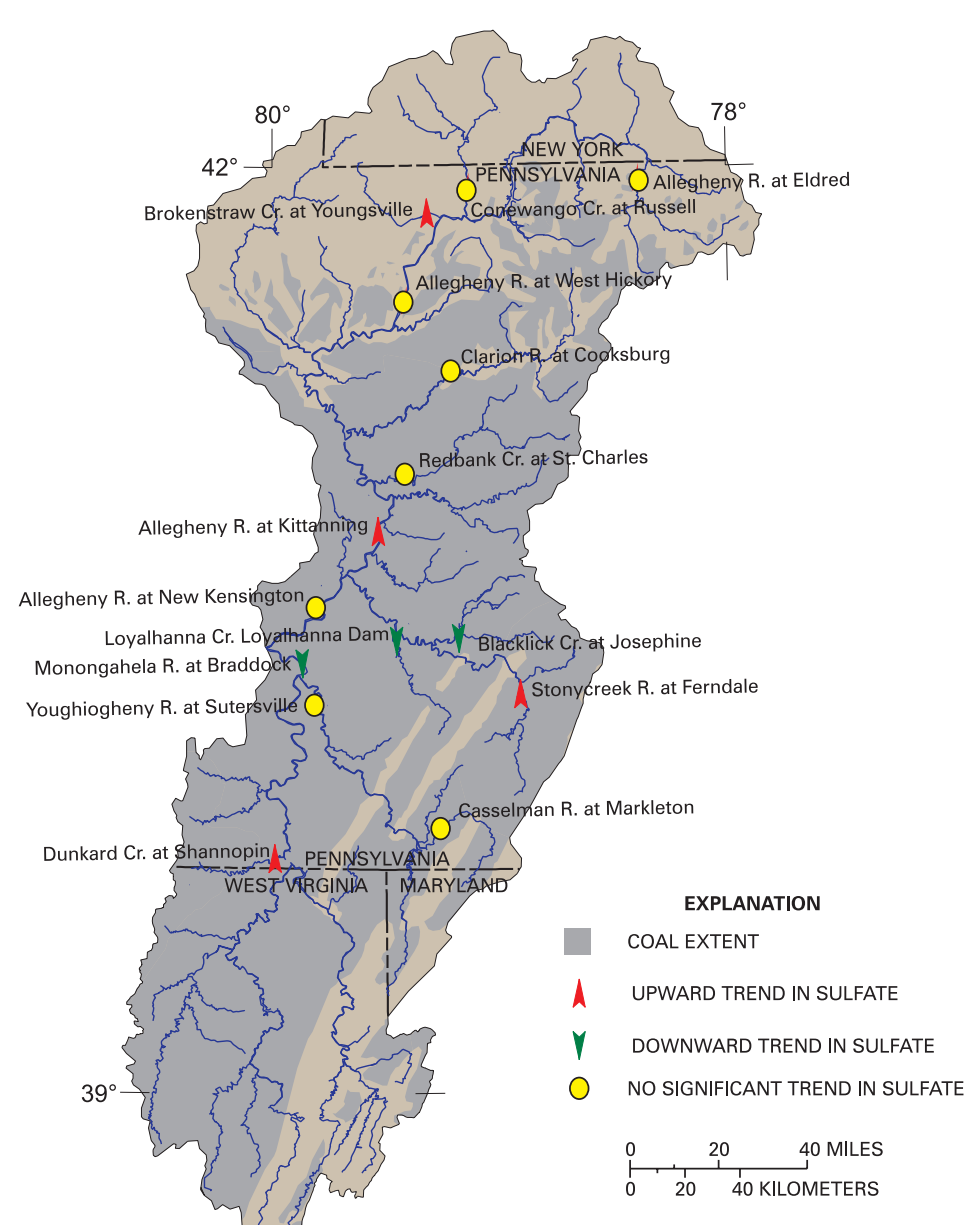

Figure 7. Trends in sulfate concentrations for water-quality monitoring sites (1965-95). 

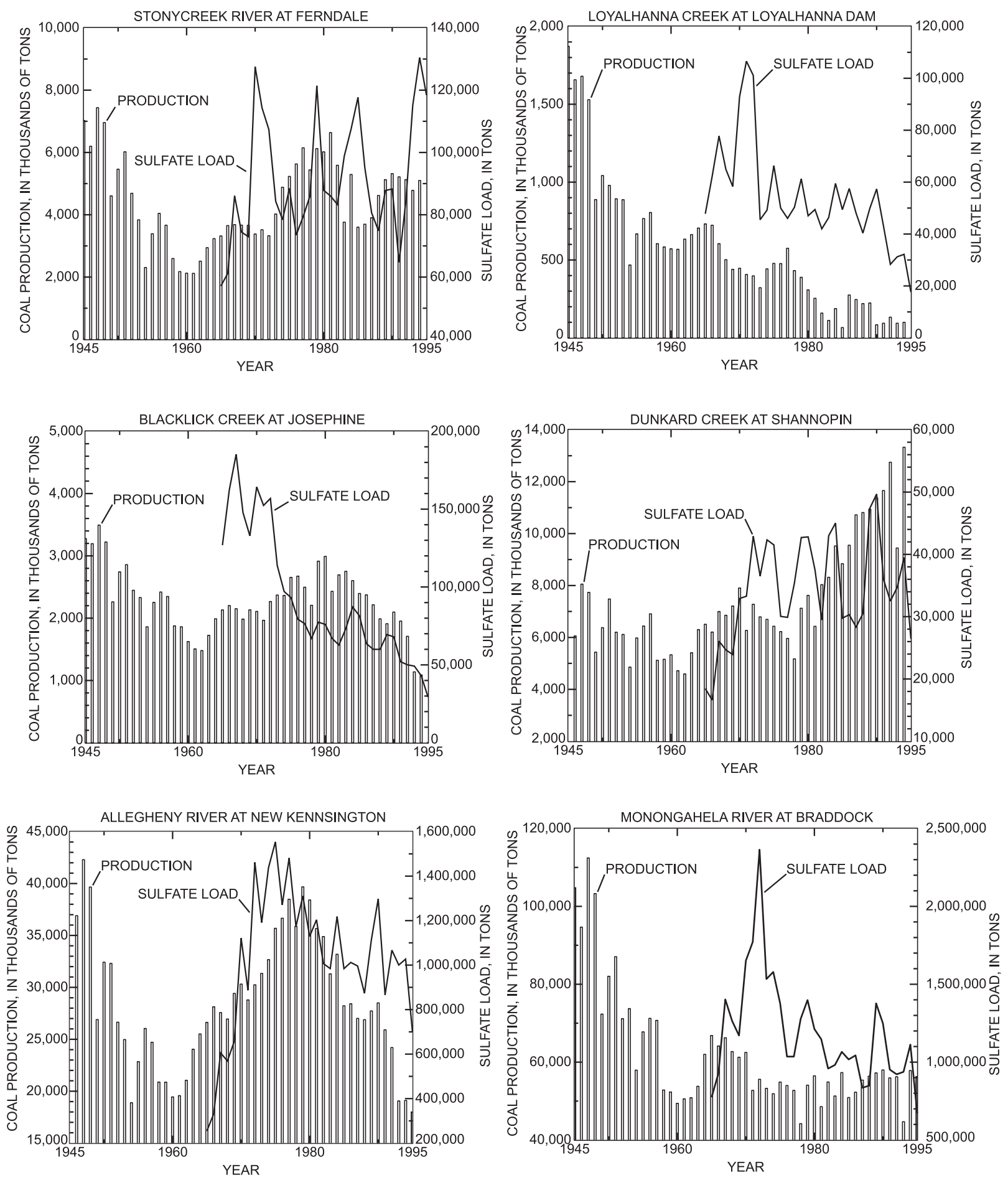

Figure 8. Estimated coal production and sulfate loads for selected coal-mined subbasins in the Allegheny and Monongahela River Basins. 
Significant, but opposite, trends noted for the Monongahela River at Braddock and Allegheny River at Kittanning are more difficult to explain because of the large basin sizes-7,337 and $8,973 \mathrm{mi}^{2}$, respectively. Monongahela River at Braddock had a 23-percent decrease in sulfate concentration; Allegheny River at Kittanning had a 23-percent increase in sulfate concentration.

As the generation of mine drainage progresses through stages of initiation, propagation, and termination at individual mine sites and no new sulfide sources are exposed, concentrations of sulfate, acidity, and metals should decrease and eventually return to levels noted in unmined basins. Sulfate concentrations in the Loyalhanna Creek Basin have been steadily decreasing since 1950 (fig. 9). This trend is a function of decreasing coal production, reclamation of abandoned mine lands, mine-drainage treatment, and natural weathering of sulfide minerals. The flattening of the curve in figure 9 indicates further decreases in sulfate concentrations will occur slowly, and mine drainage will continue to affect water quality in Loyal hanna Creek for many years. This response should be similar for other streams and rivers affected by AMD in the Allegheny and Monongahela River Basins.

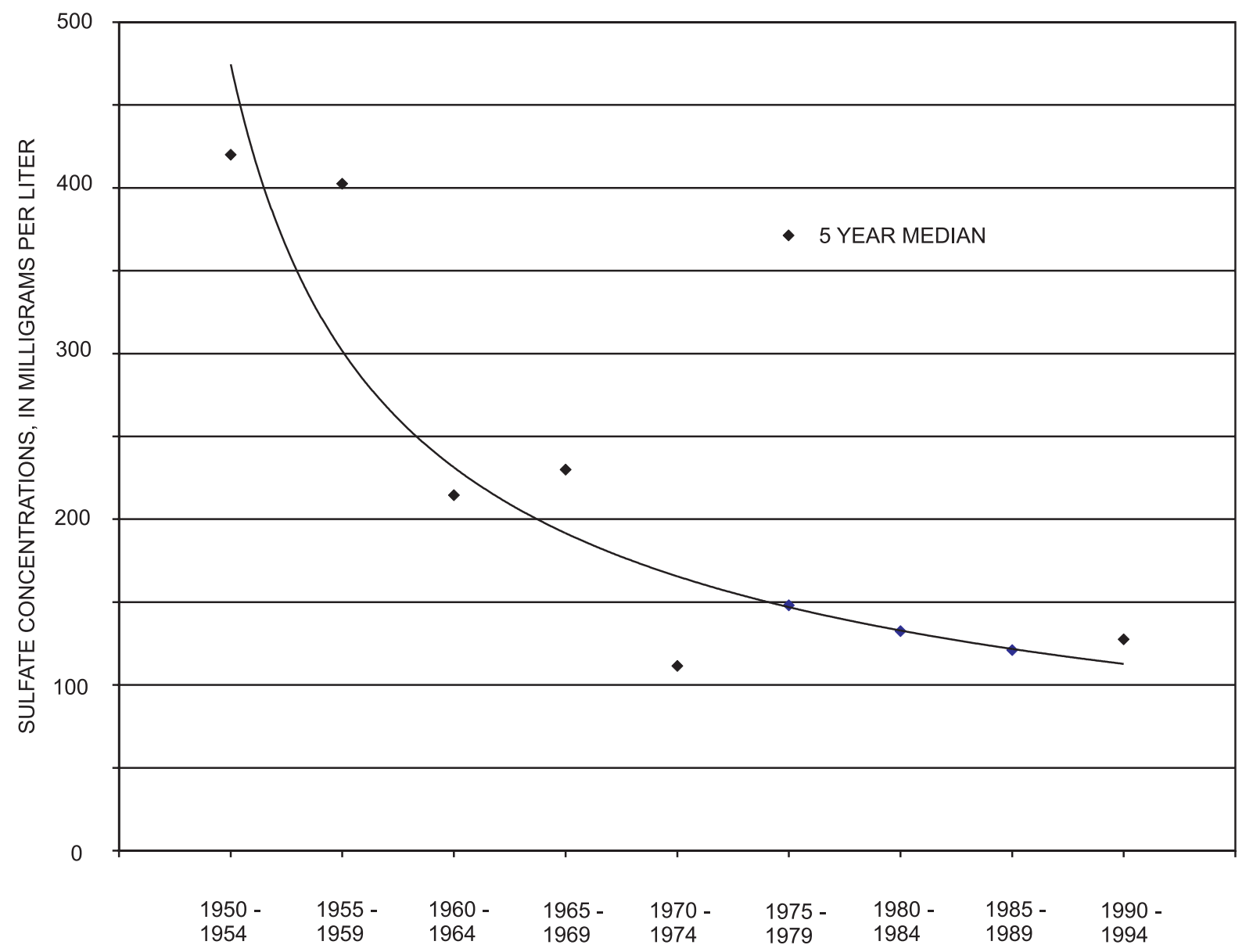

Figure 9. Median 5-year sulfate concentrations for the Loyalhanna Creek Basin, 1950-95. 


\section{SUMMARY AND CONCLUSIONS}

Historical sulfate data for major streams and rivers within the Allegheny and M onongahela study unit of the NAWQA (National Water-Quality Assessment) Program were compiled to evaluate the status and trends of the effects of coal-mine drainage on water quality. Acid mine drainage (AMD) from coal mining has been identified as having the most widespread effect on water quality in the Allegheny and Monongahela River Basins. AMD discharging from deep mines and surface mines usually results in elevated concentrations of acidity, iron, manganese, aluminum, and sulfate in receiving streams and rivers. The environmental effects from 200 years of coal mining have resulted in 2,390 stream miles in the Allegheny and Monongahela River Basin that have been affected by acid mine drainage to the point of not being able to support fish communities. Most mine drainage emanates from abandoned mines that were in operation prior to the modern mining regulations established by SMCRA. Advances in the geochemical characterization of mine sites and improvements in mining technology have substantially reduced the number of recently permitted mine sites with poor post-mining water quality. This retrospective analysis represents a comprehensive effort to quantify these effects by using sulfate loads, yields, and trends as an indicator of coal mining in the study unit.

In 1980, the Allegheny and Monongahela Rivers transported a sulfate load of 1.2 million and 1.35 million tons, respectively, to the Ohio River at Pittsburgh. The Monongahela River Basin, although smaller in drainage area $\left(7,337 \mathrm{mi}^{2}\right)$, contributed 53 percent of the sulfate load to the Ohio River at Pittsburgh compared to the Allegheny River (drainage area $11,410 \mathrm{mi}^{2}$ ). Forty-three percent of the sulfate load for the Allegheny River at New Kensington came from Blacklick Creek, Conemaugh River, Stonycreek River, Two Lick Creek, and Loyalhanna Creek. These streams and rivers combine to form the Kiskiminetas River, which enters the Allegheny River about $15 \mathrm{mi}$ below Kittanning. More than 60 percent of the sulfate load enters the Monongahela River above Greensboro, Pa.

Redstone Creek, Blacklick Creek, Conemaugh River, Buffal o Creek, Stonycreek River, Two Lick Creek, Dunkard Creek, and Loyal hanna Creek had the highest sulfate yields-from 580 to $196 \mathrm{ton} / \mathrm{mi}^{2}$ of all monitored tributary streams. These basins have been extensively mined. The sulfate yields of Brokenstraw Creek and Conewango Creek, which are outside the coal extent and unmined, were only 25 and 24 ton $/ \mathrm{mi}^{2}$, respectively.
Monongahela River at Braddock had a median sulfate concentration of $110 \mathrm{mg} / \mathrm{L}$ for the period 1965 to 1995. This is almost twice as high as the median concentration of $60 \mathrm{mg} / \mathrm{L}$ for samples collected from the Allegheny River at New Kensington. Based on the available GIS data, approximately 6,564 coal mines have operated within the Monongahela River Basin compared to 2,537 coal mines in the Allegheny River Basin. The Monongahela River Basin contains 2,685 abandoned mines, and the Allegheny River Basin has 910 abandoned mines. Coal mining and AMD has resulted in 1,071 mi of streams classified with a no-fish designation in the Monongahela River Basin and 1,320 stream miles so designated in the Allegheny River Basin.

Flow and seasonally adjusted sulfate concentrations were used to estimate trends for the period 1965 through 1995. Sulfate increased 38 percent in the Dunkard Creek Basin and 31 percent in the Stonycreek River Basin. This trend appears to be related to increases in coal production. Blacklick Creek at J osephine and Loyal hanna Creek at Loyalhanna Dam show significant downward trends in sulfate between 1965 and 1995; these trends coincide with decreases in coal production. Blacklick Creek Basin had a 50-percent decrease in sulfate concentration; Loyalhanna Creek Basin had a 41-percent decrease in sulfate concentration. Sulfate concentrations in the Loyalhanna Creek Basin have been steadily decreasing since 1950. However, it appears that improvements in water quality (reduction in mine-drainage constituents), which were rapid at first, show only gradual reduction as time increases. Consequently, it is likely to take many years for concentrations of metals, acidity, and sulfate to reach pre-mining concentrations.

The WQN stations maintained by Pennsylvania and West Virginia and the streamflow-gaging network of the USGS have provided data for evaluating the effects of mining on water quality in the Allegheny and Monongahela River Basins. Continued operation of this network will allow an opportunity to evaluate the effects of mining and also the effects of reclaiming and treating discharges from abandoned mine-land sites. This information will be useful in developing long term trends and accounting for tributary effects on water quality in the Allegheny and Monongahela Rivers. The techniques used in this investigation also could be used in water-quality assessments of streams and rivers throughout the coal regions of Pennsylvania and West Virginia. 


\section{REFERENCES CITED}

Cohn, T.A., Caulder, D.L., Gilroy, E.J ., Zynjuk, L.D., and Summers, R.M., 1992, The validity of a simple statistical model for estimating fluvial constituent loads-An empirical study involving nutrient loads entering Chesapeake Bay: Water Resources Research, v. 289, no. 9, p. 2,353-2,363.

Cohn, T.A., DeLong, L.L., Gilroy, E.J ., Hirsch, R.M., and Wells, D.K., 1989, Estimating constituent loads: Water Resources Research, v. 25, no. 5, p. 937-942.

Drake, C.F., 1931, Effect of acid mine drainage on river water supply: J ournal of American Water Works Association, v. 23, no. 10, p. 1,474-1,494.

Edmunds, W.E., and Koppe, E.F., 1968, Coal in Pennsylvania: Pennsylvania Topographic and Geologic Survey Educational Series 7, 29 p.

Hem, J.D., 1985, Study and interpretation of the chemical characteristics of natural water: U.S. Geological Survey Water-Supply Paper 2254, 263 p.

Hirsch, R.M., Alley, W.M., and Wilber, W.G., 1988, Concepts for a National Water-Quality Assessment Program: U.S. Geological Survey Circular 1021, $42 \mathrm{p}$.

Lewis, S.J ., 1906, Quality of water in the U pper Ohio River Basin and at Erie, Pennsylvania: U.S. Geol ogical Survey Water-Supply Paper 161, 114 p.

Lynch, J.A., Bowersox, V.C., and Grimm, J.W., 1996, Trends in precipitation chemistry in the United States, 1993-94-An analysis of the effects in 1995 of phase 1 of Clean Air Act Amendments of 1990, Title IV: U.S. Geological Survey Open-File Report 960346, $99 \mathrm{p}$.

Maryland Department of the Environment, 1994, Chesapeake Bay water-quality monitoring, river input monitoring component, level 1 data summary report, 1992: Watershed management program, Chesapeake Bay and Watershed Management Administration Technical Report 94-012, $91 \mathrm{p}$.

National Atmospheric Deposition Program, 1998, National atmospheric deposition program, 1997, wet disposition: Champaign, III., Illinois State Water Survey.

Pennsylvania Coal Association, 1994, Pennsylvania coal data: Harrisburg, Pa., Keystone Bituminous Coal Association, $16 \mathrm{p}$.

1995, Pennsylvania coal data: Harrisburg, Pa., Keystone Bituminous Coal Association, $32 \mathrm{p}$.

Pennsylvania Department of Environmental Protection, 1996, Commonwealth of Pennsylvania 1996 water quality assessment: Harrisburg, Pa., $94 \mathrm{p}$.

1998, Coal mine drainage prediction and pollution prevention in Pennsylvania: Harrisburg, Pa., p. (18-1)-(18-2).
Singer, P.C., and Stumm, Werner, 1970, Acidic mine drainage-The rate-determining step: Science, v. 167, p. 1,121-1,123.

Sobek, A.A., Schuller, W.A., Freeman, J R., and Smith, R.M., 1978, Field and laboratory methods applicable to overburdens and minesoils: U.S. Environmental Protection Agency EPA-600/2-78-054, 203 p.

Tisdale, E.S., 1936, Sealing abandoned coal mines in West Virginia: West Virginia State Department of Health, $24 \mathrm{p}$.

Toler, L.G., 1982, Some chemical characteristics of mine drainage in Illinois: U.S. Geological Survey WaterSupply Paper 1078, $47 \mathrm{p}$.

U.S. Environmental Protection Agency, 1995, Fisheries impacted by acid mine drainage [online]: [cited Nov. 10, 1998], available from World Wide Web at <http://www.epa.gov/reg3giss/datalib/metamd95.htm>.

U.S. Office of Surface Mining, 1998a, Factors controlling AMD formation [online]: Nov. 1998 [cited Aug. 24, 1999], available from World Wide Web at <http://www.osmre.gov/amdform.htm>.

U.S. Office of Surface Mining, 1998b, Abandoned Mine Land Program [online]: [cited Aug. 24, 1999], available from World Wide Web at <http://www.osmre.gov/zintro2.htm>.

U.S. Department of the Interior, 1967, Stream pollution by coal mine drainage in Appalachia: Federal Water Pollution Administration, $261 \mathrm{p}$.

Koryak, Michael, 1997, Origins and ecosystem degradation impacts of acid mine drainage [online]: U.S. Army Corps of E ngineers, Sept. 1997 [cited Aug. 24, 1999], available from World Wide Web at <http://www.orp-wc.usace.army.mil/misc/AMD_Impacts.html>.

West Virginia Office of Miners Health Safety and Training, 1997, Annual report and directory of mines 1996: Charleston, W. Va., 187 p.

Western Pennsylvania Conservancy, 1980, Coal and its consequences-Outlook of the 80's for Greene, Washington, and Fayette Counties, Pennsylvania, Pennsylvania Land Policy Project: Pittsburgh, Pa., $71 \mathrm{p}$.

Williams, D.R., Sams III, J .I., and Mulkerrin, M.E., 1996, Effects of coal mine discharges on the quality of the Stonycreek River and its tributaries, Somerset and Cambria Counties, Pennsylvania: U.S. Geological Survey Water-Resources I nvestigations Report 96-4133, $95 \mathrm{p}$.

Ziemkiewicz, P.F., and Meek, F.A., 1994, Long term behavior of acid forming rock-Results of 12 year field studies: Proceedings, International Land Reclamation and Mine Drainage Conference and the Third International Conference on the Abatement of Acidic Drainage, Pittsburgh, Pa., A pril 24-29, 1994. 